\title{
Contribuições de Humberto Maturana e Francisco Varela Para a Pesquisa em Comunicação
}

\section{Contributions of Humberto Maturana and Francisco Varela for research in Communication}

Resumo: Ao situar a relevância das tecnologias audiovisuais para pesquisa em comunicação constata-se sua singularidade na produção de saberes orientados no exercício teórico-metodológico da produção de sentido. Nesse estudo, tenciono problematizar aspectos relacionados à produção de conhecimento, em especial, as contribuições de Humberto Maturana e Francisco Varela para a pesquisa-intervenção em comunicação. Ressalta-se a pertinência do método de observar em oficinas de vídeo e cinema, na perspectiva de constituir práticas diferenciadas nos modos de cartografar processos de produção de subjetividade.

Palavras-chave: Comunicação. Tecnologias Audiovisuais. Biologia do Conhecer. Enação. Oficinas.

Abstract: The relevance of audiovisual technologies for research in Communication can be established by its unique role in the production of knowledge oriented to theoreticalmethodological exercise in the production of meaning. This study aims to investigate aspects related to the production processes of knowledge, with special attention to the contributions of Humberto Maturana and Francisco Varela for the research-intervention in audiovisual technologies. The study underscores the importance of the observation method in video-making and cinema workshops in establishing innovative practices to map the production processes of subjectivity.

Keywords: Communication. Audiovisual Technologies. Biology of Cognition. Inaction. Workshops.
GORCZEVSKI, Deisimer. Contribuições de Humberto Maturana e Francisco Varela Para a Pesquisa em Comunicação. Informática na Educação: teoria \& prática, Porto Alegre, v 12, n. 2, p. 132-146, jul./dez. 2009.

\author{
Deisimer Gorczevski \\ Universidade Federal do Ceará
}

\section{Sentidos da Comunicação}

E sse estudo apresenta-se como uma proposta para a produção de conhecimento em comunicação, em especial, as experimentações com as tecnologias audiovisuais, pensando nos saberes e práticas produtoras de singularidades inventivas. Nessa perspectiva os processos cognitivos e comunicacionais emergem como ações construtivas que surgem em uma rede composta por elementos heterogêneos, interligados, passíveis de modificações estruturais no percurso das histórias de interações em circunstâncias comuns aos multiversos compartilhados.

Nesse trabalho tenciono dialogar com os recentes estudos da comunicação, da psicologia social, da informática na educação e da biologia. Nesta composição interdisciplinar um dos desafios vem sendo a necessidade de tecer relações entre a dimensão teórica e as estratégias metodológicas, aspecto que, de acordo com Maldonado (2003), resume uma das principais dificuldades a serem enfrentadas pela área do conhecimento em comunicação.

Na sociedade, a comunicação está diretamente ligada à ideia de relação, de interação. $\mathrm{O}$ ato de pensar, conversar e, inclusive este, de escrever sobre a comunicação, tem sido considerado, no senso comum, um ato de comuni- 
cação. De modo geral, se diz que tudo que está em relação, está em comunicação.

Neste contexto é preciso distinguir o termo comunicação e seus diferentes sentidos para encontrarmos as expressões da singularidade e interdisciplinaridade deste campo de estudo. Ao observarmos os sentidos da comunicação para o Humano, apesar da similaridade com o ser vivo, encontraremos uma importante mutação, pois esta ocorre no plano da cultura, da história e da sociedade onde o processo de explicação se torna mais complexo.

Pressupondo que todo o saber se constitui na relação com outros saberes e, ou no inventário de saberes, surge um novo saber, vislumbramos alguns caminhos e atentamos para os possíveis encontros da comunicação com outras áreas do conhecimento.

A comunicação sendo meio da ciência, como da filosofia, produz sua singularidade na diversidade de comunicações. Um dos aspectos que se procura saber e, se vem rastreando neste percurso, é como se constitui o campo de estudo da comunicação. Ela pode ser estudada como um campo - as ciências da comunicação - onde outras disciplinas cruzam, formando um corpo móvel. E também pode ser estudada como uma ciência autônoma, que gera um saber próprio.

Nesse estudo, considero o fenômeno da comunicação na sua natureza plural e polifônico, onde os saberes teóricos e operacionais são produzidos e processados a partir dos encontros da experiência empírica, encontro com as multiplicidades da vida cotidiana. Dentre as tecnologias, destaca-se o audiovisual e sua incidência nos processos de singularização na produção de conhecimento-subjetividade.

\section{As Tecnologias Audiovisuais: processos e produtos de multipli- cidades}

Neste estudo a ênfase no audiovisual foi pautada tanto pela emergência e relevância da imagem para a comunidade, onde o estudo acontece, como por sua intensa predominância no cenário contemporâneo.

Fragmentação de informações, excesso de imagens, volubilidade dos sentidos, descontinuidade, simultaneidade, transformações das relações de espaço-tempo são alguns dos aspectos que descrevem a sociedade contemporânea, ou ainda, como alguns teóricos sugerem
- nao sem críticas - a civilização da imagem (CALVINO, 1990; GUBERN, 2003). Estas características, entre tantas outras, ampliam as dificuldades na análise e compreensão dos cenários emergentes, ou mesmo, instauram outros modos de operar com eles.

Diversidade de produções comunicacionais, apropriação das tecnologias de produção de áudio e imagem, intenso convívio com a programação televisiva, certa fascinação com a linguagem cinematográfica, participação em movimentos socioculturais, aprendizado com a fotografia e o processo de produção e gestão de audiovisuais comunitários e independentes. Estas foram algumas características mapeadas no bairro ${ }^{1}$ onde essa pesquisa acontece. Assim sendo, o audiovisual na perspectiva da comunicação comunitária ganha relevância, em particular, a modalidade de produção videográfica.

Nesse estudo, analisa-se fragmentos e composições socioculturais e comunicacionais. Dentre as tecnologias, destaca-se o audiovisual e sua incidência nos processos de singularização na produção de conhecimento-subjetividade. A seguir apresenta-se o audiovisual, enquanto linguagem e tecnologia central para esse estudo, situando aspectos de sua composição.

\subsection{Noções de Composição Audiovi- sual}

O termo audiovisual aparece nos Estados Unidos, justamente no período do surgimento do cinema falado e das primeiras transmissões televisivas. O vocábulo veio se definindo dentro dos chamados meios de comunicação de massa. Neste breve traçado da origem do termo, enfatizam-se as características que este conceito aporta na criação de certas narrativas, processos e produtos que conformam parte das mídias tradicionais e, sobretudo, para este estudo das mídias audiovisuais comunitárias.

Se apresentando como uma linguagem acoplada a toda uma gama de discursos e materiais de expressão que se articulam por meio de imagens e sons, o audiovisual ao se configurar em obra, seja ela, cinematográfica, televisiva e videográfica (produto de processos, formatos,

1 A escolha do Bairro Restinga, em Porto Alegre deveu-se a vínculos da pesquisadora iniciados em 1998, sendo o local de realização da pesquisa de doutorado, bem como pelo trabalho de pesquisa e intervenção do Grupo Juventude e Contemporaneidade. PPG da Psicologia Social e Institucional. UFRGS. 
suportes, tecnologias e modos de circulação diversos), é em cada uma destas modalidades, configurado de modo distinto e complexo.

Segundo Chion (1996) a imagem de um produto audiovisual, propõe frequentemente uma questão estética articulada especialmente na existência de um enquadramento que introduz questões de composição e de equilíbrio. Com esta perspectiva, o autor observa a necessidade de uma associação, ou melhor, quando as imagens estão associadas ao áudio a questão passa a ser a interação do que se vê e o texto que se escuta, sendo nessa interação que se criam efeitos ético-estéticos. Segundo o autor: “Un sonido en sí mismo suele no ser ni bello ni feo, ni equilibrado no desequilibrado [ . . . ]" (CHION, 1996, p. 152).

Na análise de Baro (1999) são as noções de enquadramento e planos que recebem atenção redobrada

El encuadre no es sólo la selección de una porción de la realidad sino también la distancia a la que se observa esa realidad (sujeto/objeto). A partir de esta concepción de encuadre (o plano) se estabelece una taxonomia antropocéntrica, que toma como referencia la figura humana. [ . . . ] En el lenguaje audiovisual, el concepto de plano tiene varios sentidos. Una de las acepciones recoge el valor de encuadre como grado de acercamiento a la realidad (la taxonomía de planos que se ha citado anteriormente). Un segundo significado del concepto de plano se refiere a la porción válida de una toma que se usa en la edición y que forma parte del producto audiovisual acabado ${ }^{2}$. También se usa el concepto plano para establecer la profundidad entre los elementos que configuran el encuadre y el observador (aquello que el/ la espectador/a ve en primer plano; los elementos más alejados están en segundo, tercer, cuarto plano). (BARO, 1999, p. 89, grifos nossos)

Nesse estudo, considera-se o audiovisual como linguagem mista, híbrida, processos e produtos de multiplicidades. E, desse modo, em suas experimentações englobam estratégias ético-estéticas definidas desde as escoIhas e os usos de distintos discursos, recursos, técnicas e processos que permitem a criação e produção de múltiplas realidades.

2 "El concepto toma se refiere al conjunto de imágenes grabadas con continuidad, es decir, las imágenes captadas desde que se presiona la tecla de registro para iniciar la grabación hasta que se vuelve a presionar la tecla para detenerla." (BARO, 1999, p. 89, nota de rodapé)
Considerando o fenômeno da comunicação audiovisual em sua dimensão polifônica interessa para analise os saberes teóricos e operacionais produzidos e processados a partir dos encontros da experiência empírica. Este saber comunicacional encontra apoio nos estudos da nova biologia com destaque para as contribuições dos pesquisadores Humberto Maturana e Francisco Varela, a seguir comentados.

\section{Contribuições da Biologia do Conhecer e da Teoria da Enação no Estudo da Comunicação}

Nesse trabalho, situo algumas contribuições para a pesquisa em comunicação provenientes dos estudos de Humberto Maturana e Francisco Varela, em especial, questões pertinentes a produção de conhecimento em comunicação audiovisual. $O$ estudo tem como referência a pesquisa realizada no doutorado em Ciências da Comunicação (GORCZEVSKI, 2007). Apresenta-se parte da analise dos métodos e procedimentos operacionais desenvolvidos no decorrer dessa pesquisa. Compostos por uma abordagem metodológica de pesquisa qualitativa orientada pela concepção de PesquisaIntervenção serão apresentados os métodos de observar e Análise Audiovisual com ênfase nas rotinas de produção de conhecimento em tecnologias audiovisuais.

A estratégia metodológica reconhece as relações de interdisciplinaridade com estudos provenientes da psicologia social, da informática na educação e de uma abordagem recente da biologia. Nesta última, principalmente, a concepção de autopoiesis desenvolvida pelos pesquisadores chilenos Humberto Maturana e Francisco Varela nos anos 70. Concebida como um sistema que, ao operar, gera toda a sua fenomenologia, a autopoiesis ocorre no metabolismo e na própria estrutura celular. Esses estudos, entre outros, nos alertam, cada vez mais, para a auto-organização e para o lugar do sujeito na produção da realidade.

A expressão autopoiesis vem do grego significando autocriação. Por sua vez, este conceito é um desdobramento de outro conceito procedente da cibernética e outras ciências, o conceito de auto-organização. Nas palavras de Maturana e Varela (1990, p. 25): "Os seres vivos se caracterizam pelo fato de, literalmente, se produzirem continuamente a si mesmos, e assim chamamos a organização que os define 
de organização autopoiética." E, pertinente a esta afirmação os biólogos acrescentam: "Os componentes moleculares de uma unidade autopoiética celular deverão estar dinamicamente relacionados em uma contínua rede de interações." (MATURANA; VARELA, 1990, p. 25)

Nessa perspectiva encontrei algumas contribuições para os estudos da área de comunicação, em particular, a afirmação de que não se concebe mais informação transmitida na comunicação (MATURANA; VARELA, 1990). Em suas trajetórias de pesquisa os biólogos perguntavam pelo viver, pelo existente, pela distinção entre máquinas e seres vivos e, nesse processo, compreenderam que não vivemos interações instrutivas que especifiquem, de fora, o que podemos conhecer ou fazer. A interação e o conhecimento dela resultante se constroem no próprio processo entre os envolvidos. Desse modo, os biólogos reafirmam que os seres humanos se produzem continuamente a si próprios numa organização autopoiética.

Neste estudo interessa, em particular, a análise que vem sendo atualizada por Maturana (1996, 1997, 1998,1999, 2001) em sua teoria denominada Biologia do Conhecer, bem como os estudos de Varela (1993,1994, 2003) em torno da Teoria da Enação desenvolvida a partir dos anos 80. Interessante observar que, embora separados em suas trajetórias de pesquisadores, ambos conservaram em seus estudos a hipótese da organização autopoiética dos seres vivos.

Varela (1993) designa como enaction, a conceitualização de um sistema cognitivo que nem depende de uma informação que se recebe, nem de uma construção unilateral de um sistema cognitivo sobre um ambiente sem estrutura. O que se encontra é uma permanente e inseparável dialética entre as duas coisas. O autor propõe que se saia do fundamento é um ou outro, para trabalhar com a especificidade do fora e do dentro, abandonando o ponto de ancoragem. Desenvolve a ideia de que existe uma cognição do corpo e considera que o "[ . . . ] fenômeno cognitivo e o fenômeno da vida são inseparáveis, pois desde o começo da vida celular do fenômeno autopoiético, vida e conhecimento são duas coisas inseparáveis." (VARELA, 1993, p. 87)

$\mathrm{Na}$ perspectiva enactiva, interessa, em particular, o conceito de cognição situada (VARELA, 2003), principalmente, por ampliar a compre- ensão do processo comunicacional no exercício da aprendizagem, bem como na comunicação humana. Nas palavras de Varela (2003, p. 91) “[ . . . ] o ato de comunicar não se limita a uma transferência de informação de um remetente a um destinatário, mas pela modelagem mútua de um mundo comum por meio de uma ação conjugada."

Investigando as implicações epistemológicas, ontológicas e éticas propostas pela Biologia do Conhecer e a Teoria da Enação, observo, entre seus pressupostos básicos, a construção do conhecimento como inseparável da construção de subjetividade, o próprio ato de observar, de conhecer, constitui o observado, o conhecido, numa relação indissociável. A emergência do humano e da realidade são constituídas pelos próprios observar e viver, jamais podendo ser vistas como independentes.

\section{Pesquisa-I ntervenção em Tecn- ologias Audiovisuais e os Métodos e Procedimentos Operacionais}

Este percurso vem sendo configurado num contínuo exercício de refinamento teórico-metodológico e, assim sendo, orientado na perspectiva da construção de um método de análise audiovisual. Partindo de uma abordagem metodológica de pesquisa qualitativa foram selecionados métodos e técnicas que contemplassem a análise das produções audiovisuais.

Uma das estratégias para dar conta do arcabouço teórico-metodológico vem sendo operada com as contribuições da proposta de Pesquisa-Intervenção assim como aparecem nos estudos de Maraschin (2004) e Vizer (2003). Este método de pesquisa orienta a aproximação ao campo considerando que pesquisador e pesquisado (sujeito e objeto) se constituem ao mesmo tempo, numa busca de questionamento do sentido da ação. O caráter de pesquisa acompanha a intervenção, pois esta só é possível a partir da construção de um campo conceitual que dê conta da complexidade da problemática que o contexto social nos apresenta.

Na afirmação da impossibilidade de neutralidade a pesquisa-intervenção procura romper as barreiras entre sujeito que conhece e objeto a ser conhecido, pois ambos são produzidos na realização de suas práticas.

Esse enfoque metodológico foi desenvolvido, primeiramente, a partir do trabalho do Grupo 
de Pesquisa-Intervenção Juventude e Contemporaneidade ${ }^{3}$. Participei do grupo desde a sua formação, e após um período de estudos e trocas de experiências, passamos a desenvolver um projeto de extensão ${ }^{4}$. Participaram desse processo dezoito oficineiros, todos moradores do bairro Restinga, em Porto Alegre que trabalham com temáticas das mais variadas, tais como: rádio comunitária, vídeo popular, fanzine, grafite, desenho, teatro, capoeira, hip hop e temas ligados aos direitos humanos.

O projeto articulava ações de ensino, pesquisa e extensão, potencializando o processo de qualificação de estudantes, pesquisadores e oficineiros que trabalham no contexto comunitário. A pesquisa acompanhava a intervenção na construção de um plano conceitual que buscava dar conta da complexidade da problemática no contexto social. A intervenção se sustentava em processos de análise institucional que buscaram desenvolver ações educativas e comunicacionais através de gestão compartiIhada. As relações da equipe de estudantes e pesquisadores com oficineiros produziram intervenções a partir de seus componentes teóricos, tecnológicos, estéticos, éticos, econômicos, políticos, afetivos, constituindo um plano de autoria.

O trabalho foi analisado e sistematizado e, posteriormente, efetivada a publicação ${ }^{5}$. Simultaneamente, editamos - oficineiros e pesquisadores - um vídeo também intitulado Vivenciando a Cultura na Restinga. No transcorrer dessa experiência, apresentada aqui de modo bastante resumido, foi possível refinar o que venho denominando de uma postura metodológica na perspectiva da Pesquisa-Intervenção.

Na seqüência, apresento os métodos e procedimentos operacionais propostos para a realização de estudos em comunicação, em especial, em tecnologias audiovisuais. Compostos por uma abordagem metodológica de pesquisa qualitativa orientada na perspectiva da Pesqui-

3 PPG Psicologia Social e Institucional da UFRGS.

$4 \mathrm{O}$ projeto contemplado pelo Edital MEC/Sesu com o nome de Juventude e Vulnerabilidade Social - Oficinando com Adolescentes. No entanto, o nome foi alterado para Vivenciando a Cultura na Restinga quando passou a ser implementado em conjunto com os oficineiros do bairro Restinga.

5 Caderno Vivenciando a Cultura na Restinga. Elaborado por oficineiros, estudantes e pesquisadores participantes do projeto de extensão coordenado pela Pós Graduação em Psicologia Social e Institucional da UFRGS, 2007.
sa-Intervenção serão articulados os métodos de Observar e Análise Audiovisual com ênfase nas rotinas de produção. Desse modo, tenciono coletar os traços de singularidades de um percurso de produção audiovisual, em oficinas ${ }^{6}$.

\subsection{As Oficinas de Comunicação Audiovisual}

As oficinas de comunicação audiovisual emergem como modalidade de conversação, particularmente no processo de construção do mapa das rotinas de produção audiovisual. Ao longo da pesquisa, as oficinas foram consideradas espaços de pesquisa-intervenção e, desse modo, figuravam como coadjuvantes, serviam como espaços para observar, mas não eram consideradas, em si, espaços de produção em tecnologias audiovisuais, restringindo a análise desta modalidade. Nesse momento, opta-se por promovê-la, no sentido de analisá-la, por um lado como intervenção e, por outro, como espaço de produção, em especial, de audiovisuais comunitários.

Entre as oficinas temáticas, a comunicação passou a ser uma das mais difundidas entre os jovens. Muitos deles freqüentaram oficinas dentro e fora do bairro e, inclusive, alguns deles são oficineiros ${ }^{7}$ em áreas como rádio, vídeo, fotografia, informática, fanzine, dança, grafite e teatro. Desde que iniciei minhas incursões no bairro, tive a oportunidade de observar diversas oficinas, em especial, as desenvolvidas pelos integrantes do grupo Ação Periférica na Comunicação - APC.

Outro processo importante para reconhecer as oficinas como espaço de intervenção foram as observações nas quatro oficinas - uma delas denominada oficina de comunicação - todas coordenadas por oficineiros, no Projeto de Extensão, citado anteriormente. No total, participaram dezoito adolescentes das escolas, sob coordenação de pequenos grupos de oficineiros e com acompanhamento de estudantes e pesquisadores do grupo de pesquisa, citado anteriormente.

Nesse processo de análise das oficinas que

6 Os estudos de Zaniol (2005) contribuíram na problematização do que se entende por oficinas nesse estudo.

7 Entre os jovens (doze) com os quais tive maior contato, observei a atuação de oito deles como oficineiros, sendo entrevistados dois deles (Alberto e Hermes). 
aconteceram na comunidade, passei a me perguntar o que as diferem de outras práticas sociais e comunicacionais. Escutei de alguns jovens uma distinção, inclusive, do próprio termo oficina, ou seja, por avaliarem que esta prática está se desviando do seu objetivo de construção de conhecimento e não transmissão de informações, alguns preferiram denominá-las por vivências em diferentes mídias.

Considero a oficina, nesse estudo, como uma proposta diferenciada em se tratando de analisar as rotinas de produção em tecnologias audiovisuais. Desse modo, esse processo vem sendo pensado levando-se em conta também a linguagem utilizada nas oficinas. Falar de linguagem, primeiramente, nos remete a oralidade e a escrita analisadas por alguns teóricos como línguas maiores em detrimentos de outras denominadas de línguas menores na sociedade contemporânea. Rauter (1998) chama a atenção para os modos de operar do imaginário em nossa sociedade midiatizada considerando, primeiramente, que “[ . . . ] o plano da linguagem não pode ser dissociado do contexto institucional, das relações de poder - de quem fala, onde fala, para que fala." (RAUTER, 1998, p.60) E, nesse sentido, evoca para a análise a perspectiva da esquizoanálise, reafirmando:

[ . . . ] a linguagem é sempre palavra de ordem - sempre atravessada pelo afeto, pelas relações de poder, ainda que o regime do significante busque ocultar este fato. As línguas maiores, enquanto línguas hegemônicas, línguas standart, buscarão sempre este tipo de ocultamento. As línguas menores são vias de reconexão com os afetos, intensidades, tonalidades. Porém, não há privilégio do plano da linguagem sobre outros modos de expressão. O plano das palavras e o plano das coisas permanecem numa relação disjuntiva. (RAUTER, 1998, p. 60-61)

Nas oficinas observa-se o plano da linguagem num sentido ampliado, ou seja, não nos referimos apenas à linguagem verbal, mas a uma série de expressões emergentes nas experimentações com as línguas menores. Em outras palavras, os modos de afetar e ser afetado por traços singulares, muitas vezes, ativados nos movimentos gestuais, tonalidades de voz, silêncios, atitudes e vibrações geradas nos encontros de olhares, na escuta cuidadosa, ou mesmo, nos toques sutis, entre outras sensibilidades que se produzem nas interações. Sem esquecer-se das linguagens produzidas por acoplamentos tecnológicos de toda espécie, materiais de expressão tais como: sucata, desenho, pintura, câmeras fotográficas, de vídeo, microfones, amplificadores etc. Pode-se pensar nos desdobramentos dessas linguagens em oficinas de vídeo, grafite, fanzine, etc.

O espaço de oficinar se constitui, então, como uma experiência com linguagens e tecnologias convidativas que ao aliar o desejo de inventar formas diferenciadas desses materiais de expressão, com a possibilidade de produzir algo com outros oficinantes e oficineiros potencializa o processo de problematização acerca do que está sendo produzido na oficina.

\subsection{Observar}

Ao iniciar a apresentação do que venho denominando de observar trago as aproximações com as leituras de Von Foerster (1996, 1997) e Maturana (1999, 2001) que problematizam esta questão, partindo de diferentes áreas do conhecimento.

Nos estudos da segunda cibernética foi inserida a figura do observador como participante permanente das observações e explicações, científicas ou não. Esse foi o modo de Von Foerster $(1996,1997)$ analisar a atuação dos pesquisadores. $\mathrm{O}$ autor procurou mostrar que, para a ciência tradicional, os investigadores se consideravam observadores externos. Com os estudos de autores como Humberto Maturana e Francisco Varela, em parte apresentados anteriormente, o observador conquistou especificação biológica, ganhou vida. Assim, esse nascimento tardio, essa descendência da segunda geração da cibernética - e não da primeira - fez toda a diferença, em relação à tradição desses estudos, para o modo como o autor formulou e propôs soluções para as questões relativas ao conhecimento e à linguagem.

Ao analisar a ciência sob uma ótica que não é nem lógica, nem histórica, mas científica, Maturana $(1999,2001)$ propõe uma epistemologia, e é desse modo que, produzindo uma teoria científica da cognição, explica o conhecimento enquanto atividade biológica humana. Analisa o fenômeno da percepção como aquele que se diferencia do modo usual de concebê-lo. Um ato de captação de traços de um mundo exterior, obtido pela captura de uma suposta realidade externa, independente de um observador. Desse modo, o fenômeno da percepção é subjetivo, determinado pela estrutura do sujeito cognocente, pois aquilo que é visto é 
percebido a partir do observador. Nas palavras desse pesquisador:

[ . . . ] quando um observador sustenta que um organismo exibe percepção, o que esse observador vê é um organismo que constitui um mundo de ações mediante correlações senso-motoras congruentes com as perturbações do meio no qual o observador o distingue, conservando sua adaptação. (MATURANA, 1999, p. 80).

Os termos - observar, observador, observação e experiência - não implicam, nesse contexto, apreensão de um objeto, pois, para os biólogos chilenos, a experiência se passa no suceder do viver do observador, sendo algo que nos ocorre em nosso viver cotidiano, que é um viver imerso na linguagem. Observar, assim como experienciar é vivenciado, faz parte de nosso existir. Quando enuncia “tudo que é dito é dito por um observador a outro observador que pode ser ele ou ela mesma", Maturana (2001, p. 37 está dizendo algo que evoca uma nova postura e, ao mesmo tempo, parece tão conhecido. Coisas não dizem nada, tudo que é dito é dito através da linguagem e na linguagem se encontram os sistemas vivos; somos nós, observadores, que vivemos na linguagem.

Neste método, os procedimentos operacionais são delineados, simultaneamente à composição dos mapas, nesse caso, das rotinas de produção audiovisual. Na própria constituição do mapa, passa-se a delinear as características do território. Nos procedimentos opera-se com materiais de expressão visual, sonora e audiovisual, sendo permanente o uso de um caderno de anotações onde - além das primeiras impressões, intuições, e dados básicos - serão registrados os aspectos que afetam o olho, o corpo, enfim as dimensões sensíveis dos encontros e desencontros nas rotinas de produção audiovisual.

\subsection{Análise Audiovisual com Ênfase nas Rotinas de Produção}

Para além das visões pedagógicas, instrumentais, ilustrativas e de resgate histórico, a analise audiovisual se mostra como um dispositivo atento as inúmeras formas de linguagem e de expressão que vem inovando as práticas de pesquisa-intervenção em comunicação. Paradoxalmente percebe-se o quanto esta multiplicidade de linguagens está sendo negligenciada, tanto nos processos de produção do conhecimento, nas práticas comunicacionais, como nos processos avaliativos. Deparamo-nos sempre com as marcas, as regras, os protocolos, modelos racionalistas que privilegiam a linguagem escrita em detrimento das demais.

Nessa perspectiva, encontramos algumas importantes referências nos estudos de pesquisadores preocupados com as questões da análise da imagem e do áudio. Para citar alguns exemplos, encontrei contribuições nos estudos de uma metodologia da fotoetnografia (ACHUTTI, 2004), interferindo nos modos de se conceber a pesquisa pertinente à linguagem visual e audiovisual. Como diz Arlaud, no prefácio ao estudo do antropólogo visual, este tipo de pesquisa atemoriza alguns intelectuais da área que apresentam aversões "[ .. . ] em dar à imagem um verdadeiro estatuto, outro que ilustrativo." (ARLAUD, 2004, p. 19).

Nessa mesma perspectiva de investigação, porém no campo das ciências da comunicação, encontramos os estudos de Lorite García (2004, 2006). Este autor orienta as análises da produção, bem como do produto audiovisual no domínio das Ciências da Comunicação Audiovisual. Essa orientação não descarta o uso de outras metodologias qualitativas. No entanto, afirma o potencial no aprofundamento da análise do objeto de estudo focalizando metodologias de investigação visuais e sonoras (GARCí A, 2004, p. 224).

Nas exposições de Lorite García (2004) são apresentados antecedentes, marcos e âmbitos da investigação em meios de comunicação e informação audiovisuais, bem como as perspectivas das especificidades das lógicas produtivas e de recepção em distintos meios audiovisuais. No seu estudo sobre o Tratamento informativo da Imigração na Espanha, 2002, emergem aspectos metodológicos que ampliam o leque da pesquisa em comunicação audiovisual, ou seja, “[ . . . ] tentamos mostrar o audiovisual como tal, sem precisar reduzi-lo todo ao texto [ . . . ] para que a compreensão do analisado seja mais completa e menos reducionista." (GARcíA, 2004, p. 224)

Compreende-se o método de analise audiovisual a partir da composição de três elos de problematização independentes - produção, produto e recepção-consumo - sem perder de vista os entrelaçamentos, as composições e derivações pertinentes ao processo produtivo. Avançando assim no delineamento de uma metodologia qualitativa, circunscrevo esse enfo- 
que dentro de uma perspectiva onde todo processo é considerado produção em uma esfera ou circuito de relações entre homens, natureza, indústria, sociedade, tecnologias e saberes.

Nesse estudo, enfatiza-se a analise do processo de produção audiovisual considerando, em especial, as rotinas de produção. $\mathrm{Na}$ investigação das práticas sócio-culturais e comunicacionais de grupos, instituições e comunidades, depara-se com a emergência de processos de criação e produção audiovisual diferenciados. No caso das produções audiovisuais comunitárias essas acontecem em atividades educativas denominadas oficinas de vídeo e/ou oficina de cinema. Esses exercícios de produção apresentam-se como potenciais espaços para a observação, principalmente, por serem considerados ambientes privilegiados de participação e experimentação de saberes e devires, em se tratando da produção em tecnologias audiovisuais.

As rotinas de produção realizadas em oficinas oferecem a possibilidade de se observar práticas de comunicação, em especial, por envolverem grupos heterogêneos, com participantes de distintas experiências e conhecimentos na área, num trabalho que se propõe participativo, sem a pré-definição dos papéis e lugares a serem ocupados no processo de produção, lidando com relações de poder variadas: professor-aluno, oficineiro-oficinando, coletivoindivíduo entre outros binarismos. Também se definindo por métodos de aprendizado através de vivências, onde as linguagens, os suportes e as tecnologias audiovisuais são experimentados e compartilhados desde os primeiros encontros que, em alguns casos, integram experiências de edição e pós-produção.

Reportando a estes ambientes de aprendizagem em produções audiovisuais coletivas passa-se a visualizar as contribuições teórico-metodológicas desenvolvidas pelos biólogos chilenos, em particular, a acepção que oferecem ao termo autopoiese (MATURANA; VARELA, 1990, 1997), apresentado anteriormente, bem como - conceito de cognição situada desenvolvido por Varela (2003). Para este autor o conhecimento é resultante do sentido dado a algo que emerge da capacidade de compreensão. A ação de dar sentido pode ser entendida como enatuar, ou seja, a ação de fazer acontecer o sentido a partir de uma rede de relações das quais participam o corpo, a linguagem, a história social, enfim, o que sintetiza como corporeidade. Se o dar sentido está necessariamente arraigado à nossa corporeidade biológica, ele é vivido e experimentado dentro de um domínio de ação consensual e de história cultural.

\section{Modo de Análise nas Oficinas de Produção Audiovisual}

O processo de análise das rotinas de produção de audiovisuais desenvolve-se a partir da definição de um conjunto de procedimentos teóricos-operacionais. Como destacado anteriormente, as produções audiovisuais que interessam, nesse estudo, são os realizadas em oficinas. Primeiramente, interessa as observações in loco onde acontece o processo produtivo, em particular, as experiências cognitivas e comunicacionais dos oficineiros e oficinantes. Também se considera as informações relacionadas ao contexto, bem como as leituras de documentos, relatórios e pesquisas e as conversas com representantes das instituições promotoras e apoiadores destes encontros comunicacionais.

Nesta perspectiva, retomo aspectos de um primeiro exercício de análise (GORCZEVSKI; MARASCHIN; CHASSOT, 2006) centrada na trajetória de dois oficineiros de vídeo e cinema, sendo que um deles também foi oficinante no processo de produção de outro audiovisual. A escolha por analisar as trajetórias em experiências de oficinas como método teve como justificativa a possibilidade de cartografar o processo de construção dos saberes e das práticas acontecendo.

Apresento, brevemente, os entrevistados ${ }^{8}$ destacando alguns critérios de escolhas, ou seja, aspectos que considerei relevantes para o estudo. Primeiramente, parece interessante considerar que, neste estudo: "O número de pessoas é menos importante do que a teimosia em enxergar a questão sob várias perspectivas." (GOLDENBERG, 1997, p. 50). Entre os entrevistados - Hermes e Alberto - as idades guardam certa distinção, ou seja, o primeiro tem 27 anos, o segundo tem 35 anos. Os dois concluíram o segundo grau, Hermes e Alberto são negros e moram na Restinga.

Sobre as modalidades de envolvimento de cada um deles com as mídias audiovisuais, pensando numa representação qualificada su-

8 Nesse estudo foram escolhidos nomes fictícios para os jovens entrevistados e para um outro jovem que teve sua narrativa analisada. 
gerida por Marre (1991), privilegiei os que já atuaram em mais de uma produção, tendo em comum a experiência de produzir audiovisuais a partir de oficinas.

Da análise realizada no estudo, citado anteriormente, interessou retomar questões pertinentes ao processo enativo de subjetivação. Resgatando as autonarrativas geradas desde a formulação da pergunta: Como se faz oficineiro, tenciona-se observar as subjetividades que emergem das trajetórias de vida e as práticas sócio-comunicacional dos produtores e gestores de audiovisuais. Nesse sentido, a idéia de um processo enativo de subjetivação se constitui como o que resulta de um modo de viver. No caso da análise de como se faz oficineiro:

Oficineiro é o resultante de um modo de viver como tal: falar-se, identificar-se, agir como se acredita que fala, que age um oficineiro em uma dinâmica conversacional - a oficina - que opera como uma rede de elementos interconectados capaz de sofrer alterações estruturais ao longo de uma história coletiva com certa permanência. (GORCZEVSKI; MARASCHIN; CHASSOT, 2006, p. 9).

Nesse momento, retomo a análise de aspectos do constituir-se a si numa rede múltipla e heterogênea para desenvolver, justamente, a análise do como se inventa oficineiro na relação com as distintas práticas em oficinas. Nessa visão, o ato cognitivo não se limita a uma efetividade na resolução de problemas, mas como capacidade de fazer emergir questões pertinentes à circunstância da experiência vivida. Posteriormente, o espaço-intervenção que se produz ao oficinar, bem como os modos de fazer alianças, a rede de instituições na qual a oficina se produz (escola, projeto de Descentralização da Cultura, universidade, ONG's, Associações, comunidade) e suas relações com movimentos sociais, culturais e comunicacionais ${ }^{9}$.

\subsection{Como se I nventa Oficineiro de Comunicação Audiovisual?}

O modo como os oficineiros se apresentam para o grupo - no caso especifico do projeto de extensão - evidenciou diferenças no sentido que atribuem ao fazer do oficineiro e similitudes em termos de trajetórias de vida e experimentações com diversas mídias de cunho

9 Nesse artigo não foi possível abordar a terceira dimensão, em função da delimitação de páginas. comunitário e popular. Essa narrativa de si faz transparecer um modo de problematizar a própria experiência de oficineiro ${ }^{10}$.

Hermes, ao se apresentar, diz que atua na Rádio comunitária, que tem formação alternativa, com o grupo de teatro "Ói Nóis Aqui Traveis" onde ficou por 7 anos. É militante, defende a rádio comunitária - mostra um informativo que fez sobre a rádio - e diz que vão fazer um seminário em dezembro sobre isso. Na Ação Periférica fazem "roda de comunicação" com objetivo de discutir o monopólio e a democratização dos meios de comunicação. Diz que quer aprender e que é autodidata. Fez um vídeo documentando as rádios comunitárias no III FSM - querem lutar pelos oprimidos. Acha que na reunião as pessoas não estão falando o que deveriam falar por medo e diz gostar da roda por permitir o olho-no-olho.

Alberto trabalhou como ator e oficineiro de teatro, fotografia, rádio (já foi radialista da rádio comunitária). Também já trabalhou com massagem e atualmente trabalha com vídeo. Quer trabalhar com arte e comunicação, promover mudança social, conhecer as pessoas, promover o desenvolvimento e o autoconhecimento.

A descrição inicial das trajetórias pode já trazer evidências de distintas posições e sentidos acerca do que é ser oficineiro a partir do modo como vivem essa experiência. Enquanto Hermes comenta que atua na rádio comunitária (como militante e defensor), no teatro (com uma formação alternativa) e no vídeo (produzindo um documentário), atuando junto ao grupo APC e, ao mesmo tempo, se considera um aprendiz de oficineiro e autodidata na vida, Alberto assume a atividade de oficineiro como sua ocupação principal. Estas diferenças sugerem que os sujeitos falam de um modo de viver como comunicadores comunitários e oficineiros e não somente como representam uma idéia ou uma noção de ser oficineiro de comunicação.

As falas auto-referentes anteriores também estão articuladas a uma rede de conversações que remetem ao reconhecimento dessas atri-

10 As narrativas dos jovens, coletadas em entrevistas gravadas e transcritas, posteriormente, foram realizadas pela pesquisadora, em 2005. Os relatos de campo, mais precisamente a apresentação dos jovens Hermes e Alberto - foram registros escritos tomados por uma equipe do projeto de extensão da UFRGS, em novembro de 2003. Ambas as narrativas estarão indicadas com fontes diferentes. 
buições pelos pares e, em menor dimensão, por agentes ou grupos externos, evidenciando que os processos de autoria - de constituir-se a si mesmo - se sustentam nas práticas individuais (caso do Alberto) e em processos grupais como os citados por Hermes nas rodas de comunicação do grupo APC e as experiências no Oi Nóis Aqui Traveiz ${ }^{11}$.

Ao se apresentar como oficineiro de teatro, rádio e vídeo, Alberto passou a traçar seu percurso para falar também de seus envolvimentos afetivos com a comunicação e o vídeo e, nessa narrativa autobiográfica visualizamos algumas similaridades com as experiências narradas por Hermes, anteriormente.

É que é assim: começa com a oficina de teatro, na verdade, né, teve um tempo depois que eu comecei a me questionar, tá mais o que que eu faço? Daí eu vi pô, eu acho que eu gosto de trabalhar com comunicação, porque uma hora eu tô dando oficina de teatro, outra hora eu tô numa rádio comunitária, outra hora eu tô dando oficina de rádio também, levando alunos das escolas pra rádio, e agora eu tô dando oficina de vídeo, então, quer dizer, a minha paixão maior é o vídeo, eu percebo isso, mas o que for comunicação eu gosto de transitar, né, o que tiver a ver com comunicação, e dentro da comunicação, vídeo, fotografia, rádio e teatro, porque é os instrumentos que eu tenho na mão [...].

Para Alberto, a sua própria experiência já se constitui fonte de trabalho e reconhecimento. Mas, em sua concepção, não é qualquer experiência com oficina que constitui um sujeito como oficineiro. Uma distinção fundamental é a participação em movimentos sociais. Alberto diz: "temos muitos ativistas políticos na comunidade. O oficineiro é ligado aos movimentos sociais, engajado no social". A militância e a dedicação que são definidoras de um oficineiro para Alberto guardam semelhanças com a narrativa de Hermes, embora contrastem quando se trata de constituir-se militante.

Ao dar ênfase às experimentações de Hermes e Alberto, esse estudo não se propõe a buscar as polarizações de suas narrativas como contrapontos em um contínuo, tal como oficineiro no lugar de militante que quer "lutar pelos oprimidos" (Hermes), ou oficineiro

11 Algumas pistas sobre a atuação e a influência do Grupo Ói Nóis Aqui travéiz, na Restinga, foi encontrado no livro escrito por Sandra Alencar (1997), mais precisamente, o capítulo Muito Além da Cidade Baixa. Ver também: Massa (2004). como militante que quer "promover mudança social" (Alberto). Nas narrativas de outros oficineiros, participantes do projeto de extensão, bem como de outras oficinas (como a que possibilitou a produção do audiovisual Qual Cinema), observou-se aproximações - com alguns nuances - nas coordenações de ações que, ao serem explicitadas no processo de elaboração da sistematização das experiências de oficineiros. Tais aproximações renovaram as trocas de experiências entre oficineiros, incentivando as conversações e proposições, conectando com os modos de viver como oficineiro. Um exemplo é suscitado na narrativa de outro oficineiro, que avaliou sua experiência no projeto, antes referido. Ao definir seu entendimento de "como se faz oficineiro" esse jovem, entre outros aspectos, sugere estados de: inquietação, contestação aos métodos de educação formais (ditos como acadêmicos) e experimentação de outros métodos de educação (dita como popular), afinal, para esse jovem: "[...] ser oficineiro é ser guerreiro, é resistir."

Um oficineiro surge de uma inquietação, de querer provar para as pessoas que é possível se fazer uma educação ligada a vivência, onde é possível trocar conhecimentos na prática, utilizando a amizade e o afeto como meio crucial de ligação entre oficinando e oficineiro. O oficineiro vê a necessidade de passar aquilo que sabe, pois sente que a sua prática é importante para o desenvolvimento de uma comunidade, justamente por ele viver nela. O oficineiro surge como um grito de contestação ao formalismo acadêmico, cada vez mais forte em todas as práticas populares, ser oficineiro é ser guerreiro, é resistir. (PACHECO, A. et al, 2007).

Quando Hermes se apresenta ao grupo, dizendo ser um aprendiz de oficineiro e, no decorrer do projeto, se afasta, ou melhor, participa pontualmente de alguns encontros, João chegou ao projeto se apresentando como:

[...] também do Ação Periférica atuando com rádio, música, desde 97 trabalha na Restinga, participou do Conselho de Cultura da Restinga (acabou desistindo porque não estavam fazendo o que achava que deveriam estar fazendo). Quer fazer oficina de rádio porque fechou a rádio comunitária, estão sensibilizando a comunidade. Promoveu oficinas na Faculdade de Comunicação da UFRGS. Considera importante fazer o "caminho inverso", no qual a comunidade vai até a UFRGS, já que é uma universidade pública. 
Participando de todo o processo de formação, no projeto, esse oficineiro se reaproximou também de Alberto e, algumas de suas afinidades criaram um campo de possibilidades, interferindo, inclusive, nas práticas comunicacionais e midiáticas. Um exemplo emerge com a proposição e realização de uma oficina de comunicação. Na segunda fase do projeto de extensão os oficineiros propuseram e definiram temas, prepararam, realizaram e avaliaram um conjunto de quatro oficinas, sendo uma delas a de comunicação proposta por João e apoiada por Alberto, entre outros participantes. Essa afinidade e proposição, mesmo que pontual, sugere que as trajetórias dos oficineiros - Hermes, Alberto -, protagonistas desse estudo e, as interações com outros oficineiros - nesse caso, João - podem ser lidas como processos enativos, auto-criativos, se produzindo continuamente nas conexões ativadoras da rede de conversações recorrentes que também os produzem coletivamente. “O fazer-se a si mesmo é sempre dependente de uma rede de relações de reconhecimento." (GORCZEVSKI; MARASCHIN; CHASSOT, 2006, p. 10).

Entre os aspectos presentes na pergunta como se faz oficineiro de vídeo esta o reconhecimento da relação, ou seja, como se faz oficinante de vídeo? Nesse sentido, interessou orientar a análise para a relação oficineiro-oficinando resgatando as experiências narradas por Hermes ao participar da oficina que gerou o vídeo $\mathrm{O}$ que é a Restinga e, na seqüência, o processo desencadeador da produção do vídeo Qual Cinema onde também participou Alberto. Ambos os vídeos foram realizadas através de oficinas, na Restinga, em período e condições distintas. O primeiro partiu do projeto de oficinas na Descentralização da Cultura, sendo a oficina coordenada pela professora Denise Cogo, em 1996, e o segundo fruto de uma oficina realizada na primeira edição do Festival ZoomCineEsquemaNovo, com apoio do projeto de Descentralização da Cultura, coordenada pelo professor Gilson Vargas, em 2003.

Os audiovisuais foram produzidos em oficinas que receberam, não por acaso, distintas denominações. A primeira foi proposta como oficina de vídeo integrando a programação do projeto de Descentralização da Cultura. Nesse processo, o vídeo O que é Restinga foi visto como produto de políticas públicas, inclusive pelos jovens produtores audiovisuais. Nas palavras de Hermes, “[...]o vídeo saiu institucional, não teve opção, não, fazer uma ficção, fazer uma outra coisa, uma troca de linguagem, isso não foi discutido na oficina, se existia outra, foi institucional, feito institucional".

A segunda oficina, divulgada como oficina cinema possível, fez parte de um festival de audiovisuais, promovido por um grupo de cineastas independentes que, ao encaminharem o projeto do festival a diversos órgãos públicos e privados, receberam apoio financeiro e logístico do governo estadual e municipal, através das políticas e lei de incentivo á cultura. Desse modo, esse segundo audiovisual é visto como uma espécie de produto misto (iniciativa de instituição civil com apoio de verba pública).

Retomando, as narrativas dos oficinandos Hermes e Alberto - constata-se certo encantamento com os modos de se fazer oficineiro ao descrever os métodos, técnicas usados pelo oficineiro para apresentar a linguagem do cinema. Primeiramente, resgato as narrativas de Hermes onde explica - por contrastes - suas vivencias em ambas as oficinas, destacando conteúdos, formas e características que evidencia nos modos de ensinar - a usar a ferramenta vídeo e as múltiplas linhas da linguagem audiovisual - dos respectivos oficineiros.

O primeiro, deixa eu me lembrar disso, mas o primeiro me parece que foi mais no campo de ensinar o que era um vídeo, o que era uma câmera, que película, que câmera, que película tem, entende. A oficineira, no início, no primeiro, ela fica falando mais na linha do que é o elemento que te faz fazer um vídeo que passa no cinema, mais isso. Ela trouxe, inclusive, uma palestra sobre cinema, da Casa de Cinema, com a diretora de cinema Ana Azevedo, sabe... Então, essa primeira ficou mais na ferramenta do que tu precisa para fazer vídeo, sem aquela ferramenta tu não faz, faz qualquer outra coisa, mas tu não faz vídeo, não faz câmera, né, então ela se preocupou muito mais com isso [...]. O segundo já tinha outra postura: era dentro de um festival, com um oficineiro, já tinha, já tem uma formação de oficina, já dá oficinas no Brasil, é convocado a dar oficinas. Então a oficina dele era muito mais elementos de cinema: cinema documental, cinema institucional, ah, não vamos institucional. Ele [oficineiro] já vem mais com a linha do cinema e não com a linha da película, do original, do vídeo, da ferramenta. Já mostrava vídeos com várias linguagens, uma linguagem, vídeo institucional, vídeo do Borel, que nós trouxemos [...]. Ele trouxe filme de curta metragem da Casa de Cinema, premiadíssimos, 
ficção e tal, então é mais em cima da própria linguagem do cinema.

Nesse modo de contrastar as experimentações evidenciamos os modos de enatuar, isto é, o ato de fazer emergir o sentido a partir de uma rede de conversações nas quais participam a memória, as marcas, a linguagem, a tecnologia, a produção social de vídeo e cinema, entre outros. Componentes heterogêneos atravessados por distintas concepções de como se fazer oficineiro no oficinar, no construir conhecimento e nas relações oficineiro-oficinando e vice versa, produzindo explicações em diferentes momentos, no contexto das experiências vividas em ambas às oficinas.

\subsection{A Oficina de Comunicação Audiovisual Como Espaço de Experimentações Múltiplas}

Assim como ser oficineiro e produtor audiovisual são funções que se instituem em distinções efetuadas nos modos como vivem, as oficinas de vídeo e cinema são espaços de experimentações que se produzem no próprio exercício do oficinar. A intenção é observar e cartografar como os oficinandos e, ao mesmo tempo, alguns oficineiros - em particular, Alberto $^{12}$ - adentram e ajudam a moldar esse mundo compartilhado pelas questões e problemas que sinalizam.

Nas narrativas dos protagonistas desse estudo, evidencia-se a implicação dos intercessores - teatro e rádio comunitária - atravessando de lado a lado as experimentações de oficinar e, desse modo, abertos as multiplicidades ao transitarem por lugares e fazeres de oficineiro, comunicador comunitário, produtor de audiovisuais como agenciamento múltiplo e não dual. Um exemplo foram as explicações de Alberto ao falar de sua relação com os oficinandos e os modos de oficinar a partir de suas próprias experiências enquanto oficineiro de teatro e vídeo:

Eu trago a experiência do teatro muito forte nisso. Pra mim o teatro tá dando toda a forma de se relacionar, de jogar, de brincar e até a minha postura informal com eles, de fazer todos os acordos, de ter uma aproximação informal mesmo. Sou muito parecido com eles, um

12 Alberto foi o primeiro oficineiro de vídeo no bairro. pouco mais de idade só e até por isso eles não tem um respeito formal comigo, tem um respeito de amigo, que era o que eu queria estabelecer. Então, assim, a coisa de se divertir, de tá brincando, assim, isso vem do teatro, assim, de inventar, porque, assim, o que que eu tenho assim? Tenho um conhecimento que eu quero passar, e esse conhecimento que a gente tem, não é que eu quero passar, na verdade eu quero exercitar, essa palavra é melhor assim, então pra gente exercitar esse conhecimento, tem jogos, tem brincadeiras e no teatro eu aprendi a inventar, porque outra coisa que eu me toquei, assim, eu fiquei lendo aqueles 101 exercícios para atores e não atores do Augusto Boal, tudo isso aqui foi inventado, e a gente inventa em função do que a gente quer, então eu invento às vezes, os jogos, os exercícios. E daí, teve um momento no teatro que eu vi assim, quando eu não tava bem, eu levava tudo anotado, quando eu tinha alguma dúvida, porque a gente tem que ter a carta na mão, pra quando, porque, nem sempre tu tem que tá criativo, às vezes tu tem que ter a técnica mesmo, mas quando tu tá criativo tu cria em cima da técnica, tu inventa. Então, eu espero aqueles momentos que eu tô bem em casa, eu sei o que eu quero trabalhar eu busco o melhor exercício, o melhor jogo, enfim, a melhor dinâmica pra trabalhar aquele conhecimento. Então, tem muito de teatro, assim.

Se na narrativa de Alberto, o teatro é tratado como um agenciamento, uma multiplicidade em potencial, onde as dinâmicas, os jogos e o processo de invenção e reinvenção da técnica devem ser usados a favor do tema, e não só como técnica pela técnica. Nas experiências de Hermes as oficinas tomam lugar de destaque, no processo de construção do conhecimento, sendo elas compostas por um amplo leque de modalidades expressivas. Cabe destacar também os desejos e experimentações na gestão da rádio comunitária, em jornal e na produção audiovisual.

Eu acho que é uma experiência, oficina fotografia, oficina de vídeo, oficina de cinema, oficina de, tudo que imaginar, já fiz grafite que, na área da comunicação, eu sempre fui uma pessoa extremamente descolada, nesse sentido de tá me apropriando dos conhecimentos que são acessíveis; estar muito descolado com o conhecimento. Então, eu, só eu nunca acabei voltando para uma área, me especializando numa área específica [...] conhecimento específico, numa área, não, porque eu tenho uma formação libertária que eu acredito que tu podes fazer todas as coisas bem, claro, nós queremos gestionar uma rádio, queremos gestionar uma TV, um jornal. Se a gente conseguir fazer dessa rádio, nós fizemos uma 
rádio que dure aqui, nós, muito logo a gente vai ter que envolver os produtores de vídeo, tal, fazer cinema da comunidade, tal, eles vão ter que ser protagonistas.

As oficinas são, em muitos aspectos, consideradas espaços que possibilitam alisamentos nas superfícies segmentadas através de práticas inventivas. Em outras palavras, as práticas de oficinas emergem como alternativas aos modos de ensinar das instituições macropolíticas de educação formal, sejam elas públicas ou privadas.

\section{Conclusões em Movimento}

Esse estudo apresentou-se como uma proposta para a produção de conhecimento em oficinas de comunicação audiovisual, pensando nas práticas produtoras de singularidades inventivas e na composição de saberes interdisciplinares nos estudos da comunicação. Nessa perspectiva os processos cognitivos e comunicacionais emergem como ações construtivas que surgem em uma rede composta por elementos heterogêneos, interligados, passíveis de modificações estruturais no percurso das histórias de interações em circunstâncias comuns aos multiversos compartilhados.

Os recentes estudos da nova biologia apresentam distintas contribuições para os estudos da comunicação. Nesse texto foram visitados conceitos potenciais na perspectiva de uma epistemologia da comunicação. Em especial, percorremos rastros deixados por alguns estudos de Humberto Maturana e Francisco Varela, partindo da problematização em torno da perspectiva epistemológica. Pergunta-se sobre os sentidos da comunicação, as tecnologias audiovisuais e os modos de produzir conhecimentosubjetividade e trata-se das noções relativas de autopoiesis, enação e observador - aspectos que compõem o debate em torno das ciências.

Em se tratando das tecnologias de comunicação, considera-se o audiovisual como linguagem mista, híbrida, processos e produtos de multiplicidades. E, desse modo, em suas experimentações englobam estratégias éticoestéticas definidas desde as escolhas e os usos de distintos discursos, recursos, técnicas e processos que permitem a criação e produção de múltiplas realidades.

Ressalta-se a pertinência do modo de ver e compreender os seres vivos e os seres humanos, e as interações cognitivas e comunicacionais sendo visualizado, para além de conceitos e modos de operacionalizá-los, um exercício continuo de tecer relações entre a dimensão teórica e as estratégias metodológicas, sendo esse, como vimos anteriormente, um dos desafios para a pesquisa em comunicação.

\section{Referências}

ACHUTTI, L.E.R. Fotoetnografia da Biblioteca Jardim. Porto Alegre: Ed. da UFRGS; Tomo Ed., 2004.

ALENCAR, S. Muito Além da Cidade Baixa. In: ALEnCAR, S. Atuadores da Paixão. Porto Alegre: Fumproarte, 1997. P. 155-169.

ARLAUD, J. Prefacio. In: ACHUTTI, L.E.R. Fotoetnografia da Biblioteca Jardim. Porto Alegre: Ed. da UFRGS; Tomo Ed., 2004. p. 17-20.

BARO, C.P. Vídeo. In: BUXÓ, M.J.; MIGUEL, J.M. (Ed.). De la investigación audiovisual: fotografía, cine, vídeo, televisión. Barcelona: Anthropos Ed., 1999. P. 79-104.

CALVINO, Í. Seis Propostas Para o Próximo Milênio. São Paulo: Companhia das Letras, 1990.

CHION, M. Sonidos en cine, sonido en video. In: FERLA, J. La revolucion del video. Oficina de publicaciones: Ciclo basico Comun. Buenos Aires: Universidad de Buenos Aires, 1996. P.149-153.

GOLDENBERG, M. A Arte de Pesquisar: como fazer pesquisa qualitativa em ciências sociais. Rio de Janeiro: Record. 1997. 
GORCZEVSKI, D. Micropolíticas da Juventude e Visibilidades Transversais: in(ter)venções audiovisuais na Restinga, em Porto Alegre. 2007. Tese (Doutorado em Comunicação) - Programa de Pós-Graduação em Ciências da Comunicação, Universidade do Vale do Rio dos Sinos, 2007, São Leopoldo, BR-RS.

GORCZEVSKI, D.; MARASCHIN, C.; CHASSOT, C. Tecnologias Audiovisuais em Oficinas Sócio-Educativas: Núcleo de Comunicação para a Cidadania. Brasília, DF: INTERCOM, 2006.

GUBERN, R. Del Bisonte a la realidad virtual: La escena y el Laberinto. 3. ed. Barcelona: Anagrama, 2003.

LORITE GARCÍA, N. Tratamiento informativo de la inmigración en España: 2002. Madrid: Instituto de Migraciones y Servicios Sociales/Ministerio de Trabajo y Asuntos Sociales, 2004.

LORITE GARCÍA, N. ¿Puede ser científica y objetiva la mirada audiovisual de la realidad migratoria. In. BATISDA, M. L. Medios de comunicación e inmigración. España. Caja de Ahorros del Mediterráneo. 2006. p. 85-96.

MALDONADO, A.E. Explorações Sobre a Problemática Epistemológica no Campo das Ciências da Comunicação. In: LOPES, M.I.V. (Org.). Epistemologia da Comunciação. São Paulo: Loyola. 2003. P. 205-226.

MARASCHIN, C. Pesquisar e Intervir: Revista da Associação Brasileira de Psicologia Social, Porto Alegre, v. 16, n. 1, p. 98-107, 2004.

MARASCHIN, C. Redes de Conversação como Operadoras de Mudanças Estruturais na Convivência. In: PELLANDA, N.; SCHLÜNZEN, E.; SCHLÜNZEN, K. Jr. (Org.). Inclusão Digital: tecendo redes afetiva/cognitivas. Rio de J aneiro: DP\&A, 2005. P. 135-143.

MARASCHIN, C.; CHASSOT, C.; GORCZEVSKI, D. Saberes e Práticas de Oficineiros: análise de uma cognição situada. Revista PSICO, Porto Alegre, v. 37, n. 3, p. 287-296 set./dez. 2006.

MARRE, J.L. História de Vida e Método Biográfico. Cadernos de Sociologia: metodologias de pesquisa, Porto Alegre, v. 3, n. 3, p.89-141, jan./jul. 1991.

MASSA, C. Histórias Incompletas: as Oficinas Populares de Teatro do Projeto de Descentralização da Cultura. Porto Alegre: Unidade Ed. da SMC, 2004.

MATURANA, H. La realidad: Objetiva o Construida: fundamentos biológicos de la realidad. Barcelona: Ed. Anthropos, 1996. V. 1.

MATURANA, H. Que es ver? Per capiere. In. EI SENTIDO de Lo Humano. 9. ed. Santiago do Chile: Dólmen, 1997. p. 161-195.

MATURANA, H. Da Biologia à Psicologia. Porto Alegre: Artes Médicas, 1998.

MATURANA, H. Ontologia da Realidade. Belo Horizonte: Ed. UFMG, 1999.

MATURANA, H. Cognição, Ciência e Vida Cotidiana. Belo Horizonte: Ed. UFMG, 2001.

MATURANA, H.R.; VARELA, F. El árbol del conocimiento: Las bases biológicas del entendimento humano. Santiago de Chile: Ed. Universitária, 1990.

MATURANA, H.R.; VARELA, F. De Máquinas e Seres Vivos: Autopoiese: a organização do vivo. Porto Alegre: Artmed, 1997.

PACHECO, A. et al. Vivenciando a Cultura na Restinga. Porto Alegre: Ed.UFRGS, 2007. 
PELLANDA, N.; SCHLÜNZEN, E.; SCHLÜNZEN JR., K. (Org.). Inclusão Digital: tecendo redes afetiva/cognitivas. Rio de Janeiro: DP\&A, 2005.

RAUTER, C. Clínica do Esquecimento: construção de uma superfície. 1998. Tese (Doutorado) - Programa de Estudos Pós-graduados em Psicologia Clínica, Pontifícia Universidade Católica de São Paulo, 1998, São Paulo, BR-SP.

VARELA, F. Conhecer: as ciências cognitivas: tendências e perspectiva. Lisboa: Instituto Piaget, 1987.

VARELA, F. Entrevista concedida a Rogério da Costa. In: COSTA, R. (Org.). Limiares do Contemporâneo. São Paulo: Escuta, 1993. P. 73-97.

VARELA, F.; THOMPSON, E.; ROSCH, E. A Mente Incorporada: ciências cognitivas e experiência humana. Porto Alegre: Artmed. 2003.

VIZER, E.A. La Trama (In)visible de la vida social: Comunicación, sentido y realidad. Buenos Aires: La Crujía, 2003.

VON FOERSTER, H. Visão e Conhecimento: disfunções de segunda ordem. In: SCHNITMAN, D.F. (Org.). Porto Alegre: Artes Médicas, 1996. p. 59-74.

VON FOERSTER, H. Reflexiones cibernéticas. In. FISCHER, H.R.; SCHWEIZER, J.; RETZER, A. (Org.). El final de los grandes proyectos. Barcelona: Ed. Gedisa, 1997. P. 128-135.

ZANIOL, E. Oficinando com Jovens: a produção de autoria na Restinga. 2005. Dissertação (Mestrado em Psicologia Social e Institucional) - Universidade Federal do Rio Grande do Sul, 2005, Porto Alegre, BR-RS.

Recebido em agosto de 2009

Aprovado para publicação em dezembro de 2009

\section{Deisimer Gorczevski}

Professora na Universidade Federal do Ceará - UFC. e-mail: deisimer@gmail.com 